CLINICAL STUDY

\title{
Direct effect of methylprednisolone on renal sodium and water transport via the principal cells in the kidney
}

\author{
Thomas G Lauridsen, Henrik Vase, Jesper N Bech, Søren Nielsen ${ }^{1}$ and Erling B Pedersen \\ Department of Medical Research, Holstebro Hospital, University of Aarhus, DK-7500 Holstebro, Denmark and ${ }^{1}$ Institute of Anatomy, The Water and Salt
} Research Center, University of Aarhus, Aarhus, Denmark

(Correspondence should be addressed to T G Lauridsen; Email: thomlaur@rm.dk)

\begin{abstract}
Background: Glucocorticoids influence renal concentrating and diluting ability. We tested the hypothesis that methylprednisolone treatment increased renal water and sodium absorption by increased absorption via the aquaporin-2 (AQP2) water channels and the epithelial sodium channels (ENaCs) respectively.

Methods: The effect of methylprednisolone was measured during fasting in a randomized, placebocontrolled, single-blinded cross-over study of 15 healthy humans. The subjects received a standardized diet on day 1 , fasted on day 2 , and received $500 \mathrm{mg}$ methylprednisolone intravenously on day 3 . The effect variables were urinary excretions of AQP2 (u-AQP2), urinary excretion of the $\beta$-fraction of the $\mathrm{ENaC}\left(\mathrm{u}-\mathrm{ENaC}_{\beta}\right), \mathrm{cAMP}(\mathrm{u}-\mathrm{cAMP})$, prostaglandin $\mathrm{E}_{2}\left(\mathrm{u}-\mathrm{PGE}_{2}\right)$, free water clearance $\left(\mathrm{C}_{\mathrm{H}_{2} \mathrm{O}}\right)$, and fractional excretion of sodium $\left(\mathrm{FE}_{\mathrm{Na}}\right)$, and plasma vasopressin (p-AVP), angiotensin II (p-Ang II), aldosterone (p-Aldo), atrial natriuretic peptide (p-ANP), and brain natriuretic peptide (p-BNP).

Results: Methylprednisolone treatment increased $\mathrm{u}-\mathrm{AQP} 2, \mathrm{u}-\mathrm{ENaC}_{\beta}$, and $\mathrm{p}-\mathrm{AVP}$ significantly, but did not change u-cAMP, $\mathrm{C}_{\mathrm{H}_{2} \mathrm{O}}$, and $\mathrm{FE}_{\mathrm{Na}}$. P-ANP increased during methylprednisolone treatment, but after the increase in $\mathrm{u}-\mathrm{AQP} 2$ and $\mathrm{u}-\mathrm{ENaC}_{\beta}$. U-PGE 2 , p-Ang II, and p-BNP were unchanged. Heart rate increased and diastolic blood pressure fell.

Conclusions: Methylprednisolone increased $\mathrm{u}-\mathrm{AQP} 2$ and $\mathrm{u}-\mathrm{ENaC}$. Neither the AVP-CAMP axis nor changes in the renin-angiotensin-Aldo system, or the natriuretic peptide system seems to bear a causal relationship with the increase in either $\mathrm{u}-\mathrm{AQP} 2$ or $\mathrm{u}$-ENaC. Most probably, the effect is mediated via a direct effect of methylprednisolone on the principal cells. The lack of decrease in urinary output and sodium reabsorption most likely can be attributed to the diuretic and natriuretic properties of the increased secretion of ANP.
\end{abstract}

European Journal of Endocrinology 162 961-969

\section{Introduction}

Glucocorticoids modulate the secretion of vasopressin (AVP). AVP secretion is inhibited in Cushing's syndrome and during methylprednisolone treatment, which results in a reduced urinary concentrating ability. In Addison's disease, AVP secretion is stimulated, and urinary diluting ability is reduced. However, in healthy subjects treated with methylprednisolone, plasma concentration of AVP (p-AVP) was severely suppressed, but urinary concentrating ability remained unchanged (1). Thus, glucocorticoid treatment has an AVP-independent effect on the renal capacity to excrete water.

Aquaporin-2 (AQP2) trafficking mediates water transport across the apical cell membrane in the principal cells of the collecting ducts in the kidneys (2). The short-term regulation by AVP involves activation of $V_{2}$ receptors and subsequent trafficking of AQP2 vesicles to the apical plasma membrane, resulting in increased water permeability and absorption. The long-term regulation is due to a rapid change in AQP2 mRNA expression followed by a more slow AQP2 synthesis. From a theoretical point of view, several mechanisms could be involved in a non-AVPmediated increase in urinary concentrating ability. First, inhibition of the prostaglandin receptors on the principal cells has a synergistic effect on AVP (3). Secondly, direct stimulation of cAMP in the principal cells will increase AQP2 trafficking to the apical membrane and facilitate water transport. Thirdly, glucocorticoids might directly stimulate AQP2 trafficking and/or AQP2 synthesis. Lastly, the activity of the renin-angiotensin-Aldo system and the natriuretic peptide system might be changed during glucocorticoid treatment, and subsequently renal water reabsorption.

Cellular trafficking and synthesis of the epithelial sodium channels (ENaCs) are the pathways for sodium transport across epithelia, including the kidney 
collecting ducts. The epithelial sodium transport is regulated to a great extent by trafficking mechanisms that control ENaC expression at the cell surface. Delivery of channels to the cell surface is regulated by Aldo (and corticosteroids) and AVP, both of which increase ENaC synthesis and exocytosis respectively (4).

In mineralocorticoid receptor knockout mice, treatment with glucocorticoids induced an amiloridesensitive sodium absorption in renal cortical collecting ducts, indicating that glucocorticoids might have a direct effect on amiloride-sensitive sodium absorption in renal cortical collecting ducts (5). The increased sodium absorption in renal cortical collecting ducts of mice might be due to an increased number of ENaCs. Thus, glucocorticoids might induce an increased urinary excretion of ENaCs. However, ENaC excretion might also be increased due to other mechanisms, e.g. increased shear stress by urinary flow rate. Methylprednisolone, a synthetic glucocorticoid, was chosen for the study due to its rapid inserting effect with a very modest mineralocorticoid effect.

We wanted to test the hypothesis that methylprednisolone stimulated water and sodium absorption in the kidney via the AQP2 water channels and ENaCs. The degree of water transport via AQP2 is reflected by the level of urinary excretion of AQP2 (u-AQP2) (6). Correspondingly, the sodium transport via $\mathrm{ENaCs}$ is supposed to be reflected by the level of urinary excretion of the $\beta$-fraction of $\mathrm{ENaC}\left(\mathrm{u}-\mathrm{ENaC}_{\beta}\right)$. This is the first study to investigate the effect of methylprednisolone on urinary AQP2 and ENaC excretion in humans.

We performed a randomized, placebo-controlled, cross-over study in healthy humans to examine the effect of methylprednisolone on renal handling of water and sodium during fasting. We measured the effect of methylprednisolone/placebo on $\mathrm{u}-\mathrm{AQP} 2, \mathrm{u}-\mathrm{ENaC}$, fractional urinary excretion of sodium $\left(\mathrm{FE}_{\mathrm{Na}}\right)$, urinary excretion of prostaglandin $\mathrm{E}_{2}\left(\mathrm{u}-\mathrm{PGE}_{2}\right)$, urinary excretion of cAMP (u-cAMP), and free water clearance $\left(\mathrm{C}_{\mathrm{H}_{2} \mathrm{O}}\right)$, and on plasma concentrations of renin ( $\left.\mathrm{p}-\mathrm{PRC}\right)$, angiotensin II (p-Ang II), Aldo (p-Aldo), p-AVP, atrial natriuretic peptide (p-ANP), and brain natriuretic peptide (p-BNP).

\section{Materials and methods}

\section{Participants}

Inclusion criteria Inclusion criteria were age 18-65 years and body mass index $<30$.

Exclusion criteria Exclusion criteria were clinical signs or history of disease in the heart, lungs, kidneys, or endocrine organs; abnormal laboratory tests (blood hemoglobin, white cell count, platelet counts, plasma concentrations of sodium, potassium, creatinine, albumin, bilirubin, alanine aminotransferase, and cholesterol; blood glucose; and albumin and glucose in urine); malignancies; arterial hypertension (i.e. casual blood pressure $>140 / 90 \mathrm{mmHg}$ ); alcohol abuse (more than 21 drinks per week for males and more than 14 drinks for females); medical treatment; pregnancy; breast-feeding; lack of oral contraceptive treatment for women in the fertile age; intercurrent diseases; problems with blood sampling or urine collection; medicine abuse; donation of blood $<1$ month before the study; and unwillingness to participate.

Withdrawal criteria Withdrawal criteria were development of one or more of the exclusion criteria.

\section{Ethics}

The local medical ethics committee approved the study. All the participants received written information, and gave their written consent.

\section{Design}

The study was randomized, placebo-controlled, singleblind, and over-crossed. There was a time interval of 2 weeks between the two examinations. Each examination lasted for 3 days.

\section{Recruitment}

Participants were recruited by advertisements in public and private institutions.

\section{Diet and fluid intake}

The normal energy requirement was calculated using the formula: weight $(\mathrm{kg}) \times 100(\mathrm{~kJ}) \times$ activity factor (AF). AF ranged from 1.3 to 2.4 , with a possible extra of 0.3 for physical activity in the spare time, e.g. $30 \mathrm{~min}$ of sports 5-6 times a week. AF of 1.3 indicates no physical activity. AF of 1.4-1.5 indicates secretarial work without physical activity in the spare time. AF of 1.6-1.7 indicates secretarial work with walking during working hours and/or physical activity in the spare time, AF of 1.8-1.9 corresponds to shop assistant job (standing/walking all day), and AF of 2.0-2.4 indicates hard physical activity with or without physical activity in the spare time. The food had a specified amount of energy with carbohydrates (55\% of the total energy), protein $(15 \%$ of the total energy), and fat $(30 \%$ of the total energy). The diet consisted of three main meals and three small meals. The participants were not allowed to add any spices or sodium to the meals or to divide the meals into bigger or smaller portions. The participants drank tap water, $35 \mathrm{ml} / \mathrm{kg}$ each, for $24 \mathrm{~h}$ and nothing else. They maintained normal physical activity during the study. 


\section{Procedure}

Day 1 (24 h) The participants ate the specified diet, drank tap water, $35 \mathrm{ml} / \mathrm{kg}$ body weight, and maintained normal physical activity.

Day 2 (24 h) The participants fasted, drank tap water, $35 \mathrm{ml} / \mathrm{kg}$ body weight, maintained normal physical activity, and collected urine during $24 \mathrm{~h}$.

Day 3 The participants arrived at $0730 \mathrm{~h}$ to the laboratory. An intravenous catheter was placed in fossa cubiti on each side: one for the collection of blood samples, and the other for the infusion of ${ }^{51} \mathrm{Cr}$-EDTA and hypertonic saline. Urine was collected during the following seven periods: 0700-0930 h (P-0), 09301000 h (P-1), 1000-1030 h (P-2), 1030-1100 h (P-3), 1100-1130 h (P-4), 1130-1200 h (P-5), 1200-1230 h (P-6), and 1230-1300 h (P-7). Urine was analyzed for u-AQP2, u-ENaC, u-Osm, u-Na, u-Crea, u-cAMP, u-PGE 2 , and $\mathrm{u}^{-51} \mathrm{Cr}$-EDTA. The subjects voided in the standing or sitting position. Otherwise, they were in the supine position during the examination. Blood samples were taken every $30 \mathrm{~min}$, starting at $0930 \mathrm{~h}$ for the analysis of p-AVP, p-Osm, p-Na, p-Crea, p-albumin, and p- ${ }^{51} \mathrm{Cr}-\mathrm{ED}-$ TA. In addition, blood samples for the measurements of p-Ang II, p-ANP, p-BNP, p-PRC, and p-Aldo were drawn at $0800,1100,1200$, and $1300 \mathrm{~h}$. A total amount of $350 \mathrm{ml}$ of blood was drawn during each of the study days. The blood drawn at blood sampling was immediately substituted with isotonic saline. From 1100 to $1130 \mathrm{~h}$ (P-4), $500 \mathrm{mg}$ of methylprednisolone or placebo were infused intravenously. Blood pressure and pulse rate were measured every $30 \mathrm{~min}$ during the examination.

The participants were weighed before (day 3 at $0730 \mathrm{~h})$ and after the trial $(1330 \mathrm{~h})$.

\section{Effect variables}

The main effect variables were $\mathrm{u}-\mathrm{AQP} 2$ and $\mathrm{u}-\mathrm{ENaC}$. The other effect variables were u-PGE 2 , u-cAMP, p-AVP, $\mathrm{C}_{\mathrm{H}_{2} \mathrm{O}}$, urine volume, $\mathrm{FE}_{\mathrm{Na}}$, p-Osm, p-PRC, p-Ang II, p-Aldo, p-ANP, and p-BNP.

\section{Number of participants}

Using a significance level of $5 \%$ and a power of $90 \%$, it was calculated that 14 subjects needed to be included, while the minimal relevant difference in u-AQP2 was estimated to be $0.20 \mathrm{ng} / \mathrm{min}$ and S.D was estimated to be $0.15 \mathrm{ng} / \mathrm{min}$.

\section{Test substance}

Methylprednisolone (Solu-Medrol) was dissolved in benzyl alcohol according to the instructions given by the pharmaceutical company, and was then further diluted in $100 \mathrm{ml}$ of $0.9 \%$ saline before infusion. Placebo was $100 \mathrm{ml}$ of $0.9 \%$ saline. The test substance was prepared $15 \mathrm{~min}$ before infusion according to the randomization list.

\section{Measurements}

U-AQP2 was measured by RIA as described previously, and antibodies were raised in rabbits to a synthetic peptide corresponding to the $15 \mathrm{COOH}$-terminal amino acids in human AQP2 to which an $\mathrm{NH}_{2}$-terminal cysteine was added for conjugation and affinity purification (7). Minimal detection level was $32 \mathrm{pg} /$ tube. The coefficients of variation $(\mathrm{CV})$ were $11.7 \%$ (inter-assay) and 5.9\% (intra-assay).

U-cAMP was measured using a kit obtained from R\&D Systems, Minneapolis, MN, USA. Minimal detection level was $12.5 \mathrm{pmol} /$ tube. The $\mathrm{CV}$ were $6.9 \%$ (inter-assay) and 5.3\% (intra-assay).

$\mathrm{ENaC}_{\beta}$ was measured by a newly developed RIA. Urine samples were kept frozen at $-20{ }^{\circ} \mathrm{C}$ until assayed. $\mathrm{ENaC}_{\beta}$ was synthesized by and purchased from Lofstrand Labs Ltd, Gaithersburg, Maryland, USA. The $\beta$-ENaC antibody was raised against a synthetic peptide in rabbits and affinity purified as described previously (8). Iodination of $\mathrm{ENaC}_{\beta}$ was performed by the chloramine $\mathrm{T}$ method using $40 \mu \mathrm{g} \mathrm{ENaC}_{\beta}$ and $37 \mathrm{MBq}{ }^{125}$ I. The reaction was stopped by the addition of $20 \%$ human serum albumin. ${ }^{125}$ I-labeled $\mathrm{ENaC}_{\beta}$ was separated from the iodination mixture using a Sephadex G-25 Fine column. The assay buffer contained $40 \mathrm{mM}$ sodium phosphate $(\mathrm{pH}=7.4), 0.2 \%$ human albumin, $0.1 \%$ Triton X-100, and 0.4\% EDTA. A 1.5\% solution of $\gamma$-globulins from pig (Sigma) and 25\% polyethylene glycol 6000 (Merck) also containing $0.625 \%$ Tween 20 (Merck) was prepared using $0.4 \mathrm{M}$ phosphate buffer. Urine samples were kept frozen at $-20{ }^{\circ} \mathrm{C}$. After thawing out, urine samples were centrifuged for $5 \mathrm{~min}$ at $1.6 \times 100 \mathrm{~g}$ (3000 r.p.m). The supernatant was extracted using Sep-Pak $C_{18}$. The elution fluid used was $4 \mathrm{ml}$ of a mixture comprising 90\% methanol, 0.5\% acetic acid, and 9.5\% demineralized water. The eluates were freeze-dried and kept at $-20{ }^{\circ} \mathrm{C}$ until assayed. A mixture of $300 \mu \mathrm{l}$ of standard or freeze-dried urine eluates redissolved in $300 \mu \mathrm{l}$ of assay buffer and $50 \mu \mathrm{l}$ of antibody was incubated for $24 \mathrm{~h}$ at $4{ }^{\circ} \mathrm{C}$. Thereafter, $50 \mu \mathrm{l}$ of the tracer were added, and the mixture was incubated for a further $24 \mathrm{~h}$ at $4{ }^{\circ} \mathrm{C}$. $\gamma$-Globulin from pigs $(100 \mu \mathrm{l})$ and $2 \mathrm{ml}$ of polyethylene glycol 6000 were added. The mixture was centrifuged at $2000 \mathrm{~g}$ for $20 \mathrm{~min}$ at $4{ }^{\circ} \mathrm{C}$. The supernatant (free fraction) was poured off, and the precipitate (bound fraction) was counted in a gamma counter. The unknown content in urine extracts was read from a standard curve. For 13 consecutive standard curves, the zero standard was $70 \pm 1.6 \%$, and for increasing amounts of the $\mathrm{ENaC}_{\beta}$ standard, the binding inhibition was $69 \pm 1.4 \%$ (15.6 pg/tube), 
$66 \pm 1.5 \%$ (31.25 pg/tube), $62 \pm 1.6 \%$ (62.5 pg/tube), $54 \pm 1.5 \%$ (125 pg/tube), $40 \pm 1.4 \%$ (250 pg/tube), 26 $\pm 1.2 \%$ (500 pg/tube), $14 \pm 0.6 \%$ (1000 pg/tube), $8.2 \pm 0.4 \%$ (2000 pg/tube), and $5.1 \pm 0.3 \%$ (4000 pg/ tube). The ID50, i.e. the concentration of standard needed for $50 \%$ binding inhibition, was 322 $\pm 12 \mathrm{pg} /$ tube $(n=13)$. The non-specific binding determined by performing RIA without antibody was $1.3 \pm 0.3 \% \quad(n=13)$. The inter-assay variation was determined by quality controls from the same urine pool spiked with the $\mathrm{ENaC}_{\beta}$ standard. In consecutive assays, the $\mathrm{CV}$ were as follows: $12 \%$ (12 assays) at a mean level of $78 \mathrm{pg} /$ tube, $10 \%$ (12 assays) at a mean level of $155 \mathrm{pg} / \mathrm{tube}$, and $17 \%$ (10 assays) at a mean level of $394 \mathrm{pg} /$ tube. The intra-assay variation was determined using samples from the same urine pool in several assays at different concentration levels. At a mean level of $180 \mathrm{pg} /$ tube $(n=10)$ and $406 \mathrm{pg} /$ tube $(n=10)$, the $\mathrm{CV}$ were 6.4 and $9.0 \%$ respectively. In addition, $\mathrm{CV}$ were calculated on the basis of duplicate determinations in different assays to $9.1 \%(n=22)$ in the range $58-101 \mathrm{pg} /$ tube, $8.6 \%$ $(n=26)$ in the range $143-203 \mathrm{pg} /$ tube, $8.7 \%(n=20)$ in the range $205-421 \mathrm{pg} /$ tube, and $10.0 \%(n=68)$ in the whole range $58-421 \mathrm{pg} /$ tube. The sensitivity calculated as the smallest detectable difference at the $95 \%$ confidence limit was $10 \mathrm{pg} /$ tube in the range $58-101 \mathrm{pg} /$ tube $(n=22), 20 \mathrm{pg} /$ tube in the range $143-203 \mathrm{pg} /$ tube $(n=26), 48 \mathrm{pg} /$ tube in the range $205-421 \mathrm{pg} /$ tube $(n=20)$, and $28 \mathrm{pg} /$ tube in the whole range $58-421 \mathrm{pg} /$ tube $(n=68)$. The lower detectable limit of the assay was $34 \mathrm{pg} /$ tube. It was calculated using the average zero binding for 13 consecutive assays -2 s.D. The volume of urine used for extraction from the same pool was varied (18 different volumes in the range 250-6000 $\mu \mathrm{l}$ ), and the mean concentration measured was $89 \pm 6 \mathrm{pg} / \mathrm{ml}$. There was a highly significant correlation between the extracted volume of urine and the amount of $\mathrm{pg} /$ tube ( $r=0.99, n=18)$. Recovery of the labeled tracer during the extraction-freeze drying procedure was $94 \pm 3 \%$ $(n=13), 95 \pm 3 \% \quad(n=13), 95 \pm 2 \% \quad(n=10)$, and $95 \pm 2 \%(n=7)$ in four different pools used in several extraction procedures. When $\mathrm{ENaC}_{\beta}$ in the range 62.5-250 pg was added to urine, a highly significant correlation was found between the measured and the expected values $(r=0.981, n=12, P<0.001)$. We measured $\mathrm{u}-\mathrm{ENaC}_{\beta}$ in 12 patients with arterial hypertension treated with amiloride. During the study day, a urine sample was collected at 0800 and $1100 \mathrm{~h}$ for measurement of $\mathrm{u}$-sodium/u-creatinine ( $\mathrm{u}-\mathrm{Na} / \mathrm{u}-\mathrm{Crea}$ ). No medication was given in the morning before the collection of the first urine sample. Immediately afterwards, the usual doses of 5 or $10 \mathrm{mg}$ amiloride were given. A significantly negative correlation was found between the changes in $\mathrm{u}-\mathrm{Na} / \mathrm{u}-\mathrm{Crea}$ and changes in $\mathrm{u}-\mathrm{ENaC}_{\beta} / \mathrm{u}$-Crea $(\rho=-0.724, n=11$, $P<0.012)$.
$U-P G E_{2}$ was measured using a kit obtained from Assay Designs, Inc., Ann Arbor, MI, USA. The CV were $10.9 \%$ (inter-assay) and 6.3\% (intra-assay).

Blood samples were centrifuged for $15 \mathrm{~min}$ at $1600 \boldsymbol{g}$ at $4{ }^{\circ} \mathrm{C}$. Plasma was separated from blood cells, and kept frozen at $-20{ }^{\circ} \mathrm{C}$ until assayed. $A V P$, ANP, BNP, and Ang II were extracted from the plasma with Sep-Pak $C_{18}$ (Water Associates, Milford, MA, USA), and were subsequently determined by RIAs $(9,10)$. The antibody against AVP was a gift from Prof. Jacques Dürr, Miami, FL, USA. Minimal detection level was $0.5 \mathrm{pmol} / \mathrm{l}$. The CV were $13 \%$ (inter-assay) and $9 \%$ (intra-assay). Rabbit anti-ANP antibody was obtained from the Department of Clinical Chemistry, Bispebjerg Hospital, Denmark. Minimal detection level was $0.5 \mathrm{pmol} / \mathrm{l}$, and CV were $12 \%$ (inter-assay) and $10 \%$ (intra-assay). Rabbit anti-BNP antibody without crossreactivity with urodilatin and $\alpha$-ANP was used. Minimal detection level was $0.5 \mathrm{pmol} / \mathrm{l}$ plasma. The $\mathrm{CV}$ were $11 \%$ (inter-assay) and 6\% (intra-assay). The antibody against Ang II was obtained from the Department of Clinical Physiology, Glostrup Hospital, Denmark. Minimal detection level was $2 \mathrm{pmol} / \mathrm{l}$. The CV were $12 \%$ (inter-assay) and 8\% (intra-assay).

Aldo in the plasma was determined by RIA using a kit obtained from the Diagnostic Systems Laboratories Inc., Webster, Texas, USA. Minimal detection level was $22 \mathrm{pmol} / \mathrm{l}$. The CV were $8.2 \%$ (inter-assay) and 3.9\% (intra-assay).

PRC was determined by RIA using a kit obtained from CIS Bio International, Gif-Sur-Yvette Cedex, France. Minimal detection level was $1 \mathrm{pg} / \mathrm{ml}$. The $\mathrm{CV}$ were 14.5\% (inter-assay) and 4.5\% (intra-assay).

Plasma and urinary osmolality were measured by freezing point depression (Advanced Model 3900 multisampling osmometer).

Blood pressure was measured using a UA-743 digital blood pressure meter (A\&D Company, Tokyo, Japan).

Plasma and urinary concentrations of sodium were measured by routine methods at the Department of Clinical Biochemistry, Holstebro Hospital, Denmark.

Fractional excretion of substance $X$ was calculated as the clearance of $X$ divided by glomerular filtration rate (GFR). Free water clearance $\left(\mathrm{C}_{\mathrm{H}_{2} \mathrm{O}}\right)$ was calculated using the formula: $\mathrm{C}_{\mathrm{H}_{2} \mathrm{O}}=V \times C_{\mathrm{Osm}}$, where $V$ is the urine flow and $C_{\text {Osm }}$ is the osmolar clearance. All clearances were standardized to a body surface area of $1.73 \mathrm{~m}^{2}$.

\section{Statistical analysis}

Statistical level of significance was $P<0.05$ in all the analyses. We used a general linear model with repeated measures for comparison between methylprednisolone and placebo treatments when several measurements were done during the examination. A paired $t$-test was used for comparison between two groups. The Bonferroni correction was used when appropriate. Values are given as mean \pm s.D. 


\section{Results}

\section{Demographics}

Eighteen subjects were allocated to the study. Three subjects withdrew their consents. Fifteen participants were included in the study, nine women and six men, with a mean age of $29 \pm 8$ years. Blood pressure was $124 / 72 \pm 14 / 9 \mathrm{mmHg}$. Blood samples showed b-hemoglobin $8.5 \pm 0.8 \mathrm{mmol} / \mathrm{l}, \quad$ p-sodium 139 $\pm 2 \mathrm{mmol} / \mathrm{l}$, p-potassium $3.9 \pm 0.3 \mathrm{mmol} / \mathrm{l}$, p-albumin $44 \pm 4 \mathrm{~g} / \mathrm{l}$, p-creatinine $70 \pm 9 \mu \mathrm{mol} / \mathrm{l}$, p-bilirubin 9 $\pm 6 \mu \mathrm{mol} / \mathrm{l}$, p-transaminase $18 \pm 6 \mathrm{U} / \mathrm{l}$, p-glucose $4.9 \pm 0.9 \mathrm{mmol} / \mathrm{l}$, and p-cholesterol $4.6 \pm 0.9 \mathrm{mmol} / \mathrm{l}$.

\section{Baseline levels of urinary output and urinary sodium excretion during $24 \mathrm{~h}$}

Table 1 shows that urinary output, u-Na excretion, $\mathrm{u}-\mathrm{AQP} 2, \mathrm{u}-\mathrm{ENaC}_{\beta}$, and $\mathrm{u}-\mathrm{PGE}_{2}$ were the same during the last $24 \mathrm{~h}$ before intervention on the study days with either methylprednisolone or placebo.

\section{Effect of methylprednisolone infusion on urinary water excretion}

Table 2 shows the effect variables before, during, and after methylprednisolone infusion. We found no significant changes in $\mathrm{C}_{\mathrm{H}_{2} \mathrm{O}}$ and urine volume between methylprednisolone and placebo treatments.

U-AQP2 increased significantly by $32 \%(P<0.001)$ after methylprednisolone infusion. U-AQP2 remained significantly $(P<0.001)$ elevated compared with placebo during the rest of the investigation. Treatment with methylprednisolone did not change p-Osm. P-AVP increased significantly after methylprednisolone infusion, i.e. $28 \%(P<0.05)$ at $30 \mathrm{~min}$, and remained significantly increased compared with placebo during the following periods $(P<0.02)$. We found no significant changes in either u-cAMP or $\mathrm{u}-\mathrm{PGE}_{2}$ after methylprednisolone treatment.

Table 1 Urine volume, urinary excretion of prostaglandin $E_{2}$ (u-PGE $E_{2}$, aquaporin-2 (u-AQP2), epithelial sodium channels (u-ENaC), and total urinary sodium (u-Na) excretion during $24 \mathrm{~h}$ of fasting in a randomized, placebo-controlled, cross-over study of 15 healthy subjects. Results are shown as mean (S.D).

\begin{tabular}{lccc}
\hline & $\begin{array}{c}\text { Methylpred- } \\
\text { nisolone } \\
\text { group }\end{array}$ & $\begin{array}{c}\text { Placebo } \\
\text { group }\end{array}$ & $\begin{array}{c}\text { Level of } \\
\text { significance }\end{array}$ \\
\hline Urine volume $(\mathrm{ml} / 24 \mathrm{~h})$ & $2688(683)$ & $2693(890)$ & $\mathrm{NS}$ \\
$\mathrm{U}-\mathrm{PGE}(\mathrm{ng} / 24 \mathrm{~h})$ & $620(301)$ & $535(262)$ & $\mathrm{NS}$ \\
$\mathrm{U}-\mathrm{AQP} 2(\mathrm{ng} / 24 \mathrm{~h})$ & $1089(251)$ & $1009(217)$ & $\mathrm{NS}$ \\
$\mathrm{U}-\mathrm{ENaC}(\mathrm{ng} / 24 \mathrm{~h})$ & $139(31)$ & $123(24)$ & $\mathrm{NS}$ \\
$\mathrm{U}-\mathrm{Na}(\mathrm{mmol} / 24 \mathrm{~h})$ & $114(34)$ & $105(34)$ & $\mathrm{NS}$ \\
\hline
\end{tabular}

A paired $t$-test was used for comparison between groups.

\section{Effect of methylprednisolone on urinary sodium excretion}

Table 3 shows the effect variables before, during, and after methylprednisolone infusion. We found no significant changes in GFR, urinary sodium excretion, u-Na, and $\mathrm{FE}_{\mathrm{Na}}$ between methylprednisolone and placebo treatments. At 60 and $90 \mathrm{~min}$ after infusion, $\mathrm{FE}_{\mathrm{Na}}$ increased slightly during both methylprednisolone and placebo treatments, but no significant differences existed between the groups. U-ENaC ${ }_{\beta}$ increased significantly by $95 \%(P<0.001)$ after methylprednisolone infusion, and remained significantly $(P<0.001)$ elevated compared with placebo during the rest of the investigation.

\section{Effect of methylprednisolone on vasoactive hormones}

The effect of methylprednisolone on vasoactive hormones is shown in Table 4. Methylprednisolone treatment resulted in a $25 \%$ increase in p-ANP after $120 \min (P<0.01)$. Sixty minutes after infusion, $\mathrm{p}$-ANP was increased by $19 \%(P<0.08)$. Methylprednisolone treatment increased p-Aldo by $17 \%(P<0.05)$ at $60 \mathrm{~min}$ after the infusion. However, $120 \mathrm{~min}$ post infusion, this difference had disappeared. P-Renin, p-Ang II, and p-BNP were unchanged by methylprednisolone infusion.

\section{Blood pressure and pulse rates}

At baseline, blood pressure was 111/63 $\pm 11 / 5 \mathrm{mmHg}$, and pulse rate was $60 \pm 11$ beats/min during methylprednisolone treatment. The corresponding values during placebo treatment did not deviate significantly, blood pressure was 109/62 $\pm 9 / 7 \mathrm{mmHg}$ and pulse rate was $59 \pm 10$ beats $/ \mathrm{min}$.

Systolic blood pressure did not change significantly after methylprednisolone infusion or placebo infusion. Diastolic blood pressures were significantly reduced after methylprednisolone infusion $90 \mathrm{~min}$ after baseline and the rest of the study. The reduction was $2.6 \mathrm{mmHg}$ $(P<0.02)$ at $90 \mathrm{~min}$ and $3.8 \mathrm{mmHg}(P<0.02)$ at $120 \mathrm{~min}$. At 30 and $60 \mathrm{~min}$, there were clearer tendencies to reduced diastolic blood pressure. The diastolic blood pressure reduction was $1.9 \mathrm{mmHg}$ $(P<0.08)$ at $30 \mathrm{~min}$ and $2.0 \mathrm{mmHg}(P<0.07)$ at 60 min. Diastolic blood pressure did not change statistically significantly during the placebo treatment.

Pulse rate increased significantly during methylprednisolone treatment compared with the placebo treatment (ANOVA; $P<0.02$ ). The increase was 3 beats $/ \mathrm{min} \quad(P<0.02)$ at $30 \mathrm{~min}, \quad 6$ beats $/ \mathrm{min}$ $(P<0.001)$ at $60 \mathrm{~min}, 7$ beats $/ \mathrm{min}(P<0.001)$ at $90 \mathrm{~min}$, and 10 beats $/ \mathrm{min}(P<0.001) 120 \mathrm{~min}$ after baseline (Fig. 1). 
Table 2 Effect of i.v. methylprednisolone infusion during $30 \mathrm{~min}(500 \mathrm{mg})$ on urinary excretion of aquaporin-2 (u-AQP2), plasma arginine vasopressin $(p-A V P)$, urine osmolality $(u-O s m)$, urinary excretion of prostaglandin $E_{2}\left(u-P G E_{2}\right)$, free water clearance $\left(C_{H_{2} O}\right)$, urinary excretion of cAMP (U-cAMP) in a randomized, placebo-controlled, cross-over trial in healthy subjects $(n=15)$. U-AQP2, p-AVP, p-Osm, $\mathrm{u}-\mathrm{PGE} \mathrm{E}_{2}, \mathrm{C}_{\mathrm{H}_{2} \mathrm{O}}$, and urine volume were measured at baseline ( -60 to $0 \mathrm{~min}$ ), during infusion (0-30 min), and post infusion (30-60, 60-90, and $90-120 \mathrm{~min})$. Values are means and S.D.

\begin{tabular}{|c|c|c|c|c|c|c|}
\hline & Baseline & $0-30 \mathrm{~min}$ & $30-60 \mathrm{~min}$ & $60-90 \mathrm{~min}$ & $90-120 \mathrm{~min}$ & $P$ \\
\hline $\begin{array}{l}\text { U-AQP2 (ng/min) } \\
\text { Methylprednisolone } \\
\text { Placebo } \\
P \text { value }\end{array}$ & $\begin{array}{l}0.84(0.22) \\
0.84(0.21)\end{array}$ & $\begin{array}{l}1.11(0.29) \\
0.87(0.19) \\
<0.001^{*}\end{array}$ & $\begin{array}{l}1.06(0.23) \\
0.86(0.19) \\
<0.001^{*}\end{array}$ & $\begin{array}{c}1.05(0.28) \\
0.88(0.20) \\
<0.02^{*}\end{array}$ & $\begin{array}{l}1.13(0.25) \\
0.90(0.22) \\
<0.001^{*}\end{array}$ & $<0.001$ \\
\hline $\begin{array}{l}\text { P-AVP }(\mathrm{pg} / \mathrm{ml}) \\
\text { Methylprednisolone } \\
\text { Placebo } \\
P \text { value }\end{array}$ & $\begin{array}{l}0.92(0.21) \\
0.88(0.17)\end{array}$ & $\begin{array}{c}1.18(0.45) \\
0.89(0.19) \\
<0.02^{*}\end{array}$ & $\begin{array}{l}1.27(0.44) \\
0.93(0.21) \\
<0.02^{*}\end{array}$ & $\begin{array}{c}1.09(0.25) \\
0.92(0.26) \\
<0.02^{*}\end{array}$ & $\begin{array}{l}1.03(0.19) \\
0.99(0.26) \\
\mathrm{NS}^{*}\end{array}$ & $<0.02$ \\
\hline $\begin{array}{l}\text { P-Osm (mOsm } / \mathrm{kg} \mathrm{H}_{2} \mathrm{C} \\
\text { Methylprednisolone } \\
\text { Placebo }\end{array}$ & $\begin{array}{l}282(3.4) \\
283(4.0)\end{array}$ & $\begin{array}{l}281(5.1) \\
284(3.2)\end{array}$ & $\begin{array}{l}282(3.4) \\
283(3.0)\end{array}$ & $\begin{array}{l}281(4.5) \\
283(3.1)\end{array}$ & $\begin{array}{l}281(4.2) \\
282(3.7)\end{array}$ & NS \\
\hline $\begin{array}{l}\text { U-PGE } 2(p g / m i n) \\
\text { Methylprednisolone } \\
\text { Placebo }\end{array}$ & $\begin{array}{l}440(247) \\
402(209)\end{array}$ & $\begin{array}{l}422(249) \\
388(171)\end{array}$ & $\begin{array}{l}466(287) \\
362(185)\end{array}$ & $\begin{array}{l}447(331) \\
368(188)\end{array}$ & $\begin{array}{l}463(371) \\
386(203)\end{array}$ & NS \\
\hline $\begin{array}{l}\mathrm{C}_{\mathrm{H}_{2} \mathrm{O}}(\mathrm{ml} / \mathrm{min}) \\
\text { Methylprednisolone } \\
\text { Placebo }\end{array}$ & $\begin{array}{l}3.5(1.4) \\
4.5(2.0)\end{array}$ & $\begin{array}{l}2.4(1.4) \\
3.2(1.6)\end{array}$ & $\begin{array}{l}3.6(1.1) \\
3.3(1.4)\end{array}$ & $\begin{array}{l}3.7(1.3) \\
2.4(1.3)\end{array}$ & $\begin{array}{l}3.2(1.9) \\
2.8(1.2)\end{array}$ & NS \\
\hline $\begin{array}{l}\text { Urine }(\mathrm{ml} / \mathrm{min}) \\
\text { Methylprednisolone } \\
\text { Placebo }\end{array}$ & $\begin{array}{l}6.15(1.68) \\
7.27(2.21)\end{array}$ & $\begin{array}{l}5.11(1.59) \\
6.09(1.67)\end{array}$ & $\begin{array}{l}6.27(1.23) \\
6.23(1.47)\end{array}$ & $\begin{array}{l}6.52(1.65) \\
5.33(1.45)\end{array}$ & $\begin{array}{l}6.38(2.23) \\
5.89(1.67)\end{array}$ & NS \\
\hline $\begin{array}{l}\text { U-cAMP (pmol/min) } \\
\text { Methylprednisolone } \\
\text { Placebo }\end{array}$ & $\begin{array}{l}3850(754) \\
3811(601)\end{array}$ & $\begin{array}{l}3515(591) \\
4024(879)\end{array}$ & $\begin{array}{l}3592(575) \\
3853(694)\end{array}$ & $\begin{array}{l}3735(796) \\
3888(674)\end{array}$ & $\begin{array}{l}4022(832) \\
3649(605)\end{array}$ & NS \\
\hline
\end{tabular}

$P$ value indicates significant difference between methylprednisolone and placebo treatments using a general linear model with repeated measures. A paired $t$-test was used for comparison of means when differences were found between the two treatments *.

\section{Discussion}

The present results show that methylprednisolone given intravenously in an acute study did not change free water clearance and $\mathrm{FE}_{\mathrm{Na}}$. However, both $\mathrm{u}-\mathrm{AQP} 2$ and $\mathrm{u}-\mathrm{ENaC}_{\beta}$ increased significantly just as p-AVP, p-ANP, and pulse rate.

The amount of $\mathrm{ENaC}_{\beta}$ in urine is supposed to reflect the activity of sodium transport via the ENaCs, just as $\mathrm{u}-\mathrm{AQP} 2$ reflects the functional status of the AQP2 water channels (6). Our analyses showed that the assay has a satisfactory reliability. In addition, we demonstrated a significantly negative correlation between changes in urinary sodium excretion and changes in $\mathrm{u}-\mathrm{ENaC}_{\beta}$ during amiloride treatment. This means that the decrease in $\mathrm{u}-\mathrm{ENaC}_{\beta}$ was related to the increase in urinary excretion of sodium during amiloride treatment. Thus, our results are in accordance with $\mathrm{u}-\mathrm{ENaC}_{\beta}$ being a biomarker of the transport of sodium via ENaCs during acute studies, presumably reflecting up- and down-regulation of $\beta$-ENaC expression and sodium transport via ENaCs. However, further studies are necessary to elucidate more precisely to what degree $\mathrm{u}-\mathrm{ENaC}_{\beta}$ reflects the activity of ENaCs. Furthermore, it is not clarified which of the protein components, $\alpha-, \beta-$, or $\gamma$-fraction, in the $\mathrm{ENaC}$ will be the best biomarker for the channel.
We found that methylprednisolone clearly increased p-AVP by a non-osmotic mechanism, since methylprednisolone did not change p-Osm. This is in disagreement with other studies in animals and healthy humans, in which p-AVP was pronouncedly reduced $(1,11)$. However, we have studied the effect of a large single i.v. dose of methylprednisolone in an acute study, whereas glucocorticoid was given orally for a longer period, i.e. several days in healthy humans, and in a smaller dose $(1,11)$. These differences in design and doses may explain the discrepancy. The central mechanism for the antidiuretic action of AVP is the exocytotic insertion of AQP2 from intracellular vesicles into the apical membrane of the principal cells, an event initiated by an increase in cAMP and activation of protein kinase A (12). In our study, we found no increase in u-cAMP despite increased levels of $\mathrm{p}$-AVP, indicating that the AVP-cAMP pathway for up-regulation of AQP2 expression was not activated during methylprednisolone treatment. In addition, we measured no changes in u-PGE 2 . Thus, it is unlikely that our results could be explained by possible antagonistic effect of prostaglandins on the vasopressinergic effect on the distal part of the nephron. The principal cells in the distal part of the nephron seem to be refractory to AVP during methylprednisolone treatment, and the increase in u-AQP2 must be attributed to a non-AVP-mediated mechanism. 
Table 3 Effect of i.v. methylprednisolone infusion during $30 \mathrm{~min}(500 \mathrm{mg})$ on urinary excretion of the $\beta$-fraction of the epithelial sodium channel $\left(\mathrm{u}-\mathrm{ENaC}_{\beta}\right)$, fractional excretion of sodium $\left(\mathrm{FE}_{\mathrm{Na}}\right)$, and glomerular filtration rate (GFR) in a randomized, placebo-controlled, crossover trial in healthy subjects $(n=15)$. U-AQP2, $\mathrm{FE}_{\mathrm{Na}}$, and GFR were measured at baseline ( -60 to $0 \mathrm{~min}$ ), during infusion (0-30 min), and post infusion (30-60 min, 60-90 $\mathrm{min}$, and 90-120 $\mathrm{min}$ ). Values are means and S.D.

\begin{tabular}{|c|c|c|c|c|c|c|}
\hline & Baseline & 0-30 min & $30-60 \mathrm{~min}$ & $60-90 \mathrm{~min}$ & $90-120 \mathrm{~min}$ & $\boldsymbol{P}$ \\
\hline \multicolumn{7}{|l|}{$\mathrm{U}-\mathrm{ENaC}_{\beta}(\mathrm{pg} / \mathrm{min})$} \\
\hline Methylprednisolone & $86.6(20)$ & $160.5(57)$ & $185.6(29)$ & $143.7(26)$ & $155.8(27)$ & \multirow[t]{3}{*}{$<0.001$} \\
\hline Placebo & $84.6(22)$ & $86.8(17)$ & $80.3(16)$ & $78.8(19)$ & 87.7 (13) & \\
\hline$P$ value & NS & NS & 0.055 & 0.0001 & 0.004 & \\
\hline \multicolumn{7}{|l|}{$\mathrm{FE}_{\mathrm{Na}}$} \\
\hline Methylprednisolone & $1.04(0.43)$ & $1.08(0.39)$ & $1.17(0.43)$ & $1.18(0.35)$ & $1.10(0.36)$ & \multirow[t]{2}{*}{ NS } \\
\hline Placebo & $1.16(0.48)$ & $1.20(0.36)$ & $1.36(0.38)$ & $1.36(0.40)$ & $1.26(0.48)$ & \\
\hline \multicolumn{7}{|l|}{ GFR (ml/min) } \\
\hline Methylprednisolone & $108(19)$ & $108(13)$ & $101(13)$ & $103(15)$ & $115(16)$ & \multirow[t]{2}{*}{ NS } \\
\hline Placebo & 107 (13) & $109(15)$ & $101(11)$ & $105(14)$ & $111(16)$ & \\
\hline
\end{tabular}

$P$ value indicates significant difference between methylprednisolone and placebo treatments using a general linear model with repeated measures. A paired $t$-test was used for comparison of means when differences were found between the two treatments.

In addition to AVP, the activity in the reninangiotensin-Aldo system and the natriuretic peptide system can influence the expression of AQP2 (13-19). We measured an increase in p-ANP after methylprednisolone treatment. This is in agreement with previous studies, in which glucocorticoids up-regulated ANP in myocytes from rats (20) and modulated the ANP response to different stimuli $(11,21)$. In rats, ANP infusion had no immediate effect on the intracellular localization of $\mathrm{AQP} 2$, but apical targeting of $\mathrm{AQP} 2$ increased after $90 \mathrm{~min}$ of infusion (22). We found increased levels of u-AQP2 120 min before any changes in ANP, and due to this time dissociation, we consider it unlikely that increased ANP could be responsible for the up-regulation of $\mathrm{AQP} 2$ and subsequent increase in $\mathrm{u}-\mathrm{AQP} 2$ during methylprednisolone treatment.
According to the results from experiments with denervated rat kidneys, a reduction in sympathetic nervous stimulation reduced AQP2 expression (23), and the authors suggest that renal sympathetic nerve activity may play an excitatory role in $\mathrm{AQP} 2$ regulation. Methylprednisolone treatment induced changes in systemic hemodynamics, i.e. a decrease in diastolic blood pressure and an increase in pulse rate. The increase in pulse rate most likely reflects enhanced sympathetic nerve activity. Thus, increased renal sympathetic nerve activity during methylprednisolone treatment could play a role in the up-regulation of AQP2 water channels in our study. We did not measure an increase in plasma renin concentration, but this does not exclude that increased sympathetic adrenergic activity influences AQP2 expression as shown in animal

Table 4 Effect of i.v. methylprednisolone infusion during $30 \mathrm{~min}(500 \mathrm{mg})$ on plasma atrial natriuretic peptide (p-ANP), plasma brain natriuretic peptide ( $p$-BNP), plasma renin, plasma angiotensin II ( $p$-Ang II), and p-aldosterone ( $p$-Aldo) in a randomized, placebo-controlled, cross-over trial in healthy subjects $(n=15)$. The hormones were measured at baseline and 30 and 90 min after methylprednisolone infusion. Values are means and S.D.

\begin{tabular}{|c|c|c|c|c|}
\hline & Baseline & $30 \mathrm{~min}$ post & $90 \mathrm{~min}$ post & $P$ value \\
\hline \multicolumn{5}{|l|}{ P-ANP (pmol/l) } \\
\hline Methylprednisolone & $6.3(3.5)$ & $7.5(4.6)$ & $7.9(4.7)$ & \multirow[t]{3}{*}{$<0.01$} \\
\hline Placebo & $6.3(3.0)$ & $5.9(2.8)$ & $5.1(2.1)$ & \\
\hline$P$ value & & & $0.004^{*}$ & \\
\hline \multicolumn{5}{|l|}{ P-BNP (pmol/l) } \\
\hline Methylprednisolone & $1.7(2.3)$ & $1.8(2.3)$ & $1.8(2.5)$ & \multirow[t]{2}{*}{ NS } \\
\hline Placebo & $1.4(1.3)$ & $1.4(1.2)$ & $1.3(1.2)$ & \\
\hline \multicolumn{5}{|l|}{ P-Renin (mU/l) } \\
\hline Methylprednisolone & $7.6(4.3)$ & $15.6(25.9)$ & $13.0(25.3)$ & \multirow[t]{2}{*}{ NS } \\
\hline Placebo & $7.5(3.2)$ & $8.8(7.5)$ & $10.6(10.1)$ & \\
\hline \multicolumn{5}{|l|}{ P-Ang II (pmol/l) } \\
\hline Methylprednisolone & $12.3(6.3)$ & $13.0(8.5)$ & $12.3(8.0)$ & \multirow[t]{2}{*}{ NS } \\
\hline Placebo & $11.5(6.3)$ & $13.0(8.8)$ & $11.9(6.5)$ & \\
\hline \multicolumn{5}{|l|}{ P-Aldo (pmol/l) } \\
\hline Methylprednisolone & $284(147)$ & $334(107)$ & $269(96)$ & \multirow[t]{3}{*}{ NS } \\
\hline \multirow{2}{*}{ Placebo } & $283(228)$ & 249 (180) & $258(131)$ & \\
\hline & & $0.05^{\star}$ & & \\
\hline
\end{tabular}

$P$ value indicates significant difference between methylprednisolone and placebo treatments using a general linear model with repeated measures. A paired $t$-test was used for comparison of means when differences were found between the two treatments *. 


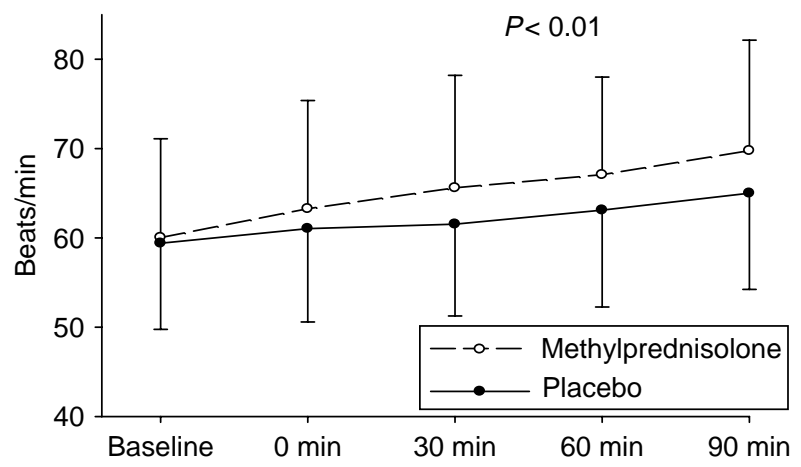

Figure 1 Effect of i.v. methylprednisolone infusion during $30 \mathrm{~min}$ $(500 \mathrm{mg})$ on the pulse rate in a randomized, placebo-controlled, cross-over trial in healthy subjects $(n=15)$. U-AQP2 was measured at baseline, immediately after infusion ( $0 \mathrm{~min}$ ), and post infusion (30,60, and $90 \mathrm{~min})$. $P$ value indicates significant difference between methylprednisolone and placebo treatments using a general linear model with repeated measures.

studies. The effect of increased renal sympathetic nerve activity has not been studied with regard to $\mathrm{ENaC}$ expression.

Although the activity of ENaCs is mainly regulated by mineralocorticoids, AVP has also some effect on sodium reabsorption via ENaCs via a cAMP/protein kinase A-mediated mechanism (24). However, the increase in p-AVP with the lack of increase in cAMP indicates that the AVP-cAMP pathway cannot be responsible for the increased u-ENaC in our study during methylprednisolone treatment.

We did not measure any decrease in either $\mathrm{C}_{\mathrm{H}_{2} \mathrm{O}}$ or $\mathrm{FE}_{\mathrm{Na}}$. This might be due to the fact that methylprednisolone has only a weak mineralocorticoid effect and a strong glucocorticoid effect. Thus, methylprednisolone has more than fourfold larger glucocorticoid effect than cortisol, whereas its mineralocorticoid effect is only $2 \%$ of the effect of Aldo when measured in cell cultures (25). However, our results clearly indicated that $\mathrm{u}-\mathrm{AQP} 2$ and $\mathrm{u}-\mathrm{ENaC}_{\beta}$ were increased during treatment with methylprednisolone. Thus, an increased tubular absorption of water and sodium must have taken place in the early phase of the treatment via the principal cells in the distal part of the nephron. Consequently, other mechanisms must have antagonized this water- and sodium-retaining effect. We measured an increase in p-ANP. Most probably, the increase in p-ANP is responsible for a compensatory increase in both urinary water and sodium excretions, and the increased anti-natriuretic effect of ANP could have masked and neutralized the expected decrease in urinary water output and sodium excretion.

In our study, the subjects fasted for 1 day. This might have increased endogenous production of glucocorticoids. However, the glucocorticoid effect of methylprednisolone is much higher than the effect of the endogenously produced cortisol. Thus, our results primarily reflect the effect of methylprednisolone.
It is the strength of our study that test conditions were very well defined regarding energy intake, diet, and fluid intake. The study was done during fasting conditions during which prostaglandin synthesis was stimulated (13). Our measurements of u-PGE 2 showed that we avoided a confounding inhibition of prostaglandin synthesis by methylprednisolone. It cannot be excluded that stress during the examination increased the endogenous steroid level, and thereby had an effect on values in the control period. This might have reduced the differences between the control and methylprednisolone periods.

We did not measure any differences in the effect variables between the group of women and the group of men in the study population. Thus, although we have studied both women and men, our results do not seem to be influenced by gender.

In conclusion, methylprednisolone clearly increased $\mathrm{u}-\mathrm{AQP} 2$ and $\mathrm{u}-\mathrm{ENaC}$. Neither the AVP-cAMP axis nor changes in the activity in the renin-angiotensin-Aldo system, or the natriuretic peptide system seem to bear a causal relationship with the increase in either $\mathrm{u}-\mathrm{AQP} 2$ or u-ENaC. Most probably, the effect is mediated via a direct effect of methylprednisolone on the principal cells in the distal part of the nephron. The lack of increase in urinary output and sodium excretion most likely can be attributed to the diuretic and natriuretic properties of the increased secretion of ANP shortly after the infusion of methylprednisolone.

\section{Declaration of interest}

The authors declare that there is no conflict of interest that could be perceived as prejudicing the impartiality of the research reported.

\section{Funding}

The trial was supported by grants from Ringkjobing County and Lundbeck Foundation.

\section{Acknowledgements}

We thank laboratory technicians Lisbeth Mikkelsen, Henriette Vorup Simonsen, Kirsten Nyborg, and Anne Mette Ravn for their skillful technical assistance and commitment, and the catering officer and the staff in the kitchen for preparing the diet.

\section{References}

1 Bahr V, Franzen N, Oelkers W, Pfeiffer AF \& Diederich S. Effect of exogenous glucocorticoid on osmotically stimulated antidiuretic hormone secretion and on water reabsorption in man. European Journal of Endocrinology 2006155 845-848.

2 Nielsen S, Frokiaer J, Marples D, Kwon TH, Agre P \& Knepper MA. Aquaporins in the kidney: from molecules to medicine. Physiological Reviews 200282 205-244.

3 Hebert RL, Jacobson HR, Fredin D \& Breyer MD. Evidence that separate $\mathrm{PGE}_{2}$ receptors modulate water and sodium transport in rabbit cortical collecting duct. American Journal of Physiology 1993 265 F643-F650. 
4 Snyder PM. Minireview: regulation of epithelial $\mathrm{Na}^{+}$channel trafficking. Endocrinology 2005146 5079-5085.

5 Schulz-Baldes A, Berger S, Grahammer F, Warth R, Goldschmidt I, Peters J, Schütz G, Greger R \& Bleich M. Induction of the epithelial $\mathrm{Na}^{+}$channel via glucocorticoids in mineralocorticoid receptor knockout mice. Pflügers Archiv 2001443 297-305.

6 Pedersen RS, Bentzen H, Bech JN \& Pedersen EB. Effect of water deprivation and hypertonic saline infusion on urinary AQP2 excretion in healthy humans. American Journal of Physiology. Renal Physiology 2001280 F860-F867.

7 Starklint J, Bech JN \& Pedersen EB. Down-regulation of urinary AQP2 and unaffected response to hypertonic saline after 24 hours of fasting in humans. Kidney International 200567 1010-1018.

8 Hager H, Kwon TH, Vinnikova AK, Masilamani S, Brooks HL, Frøkiaer J, Knepper MA \& Nielsen S. Immunocytochemical and immunoelectron microscopic localization of alpha-, beta-, and gamma-ENaC in rat kidney. American Journal of Physiology. Renal Physiology 2001280 F1093-F1106.

9 Jensen KT, Carstens J, Ivarsen P \& Pedersen EB. A new, fast and reliable radioimmunoassay of brain natriuretic peptide in human plasma. Reference values in healthy subjects and in patients with different diseases. Scandinavian Journal of Clinical and Laboratory Investigation 199757 529-540.

10 Pedersen EB, Eiskjaer H, Madsen B, Danielsen H, Egeblad M \& Nielsen CB. Effect of captopril on renal extraction of renin, angiotensin II, atrial natriuretic peptide and vasopressin, and renal vein renin ratio in patients with arterial hypertension and unilateral renal artery disease. Nephrology, Dialysis, Transplantation 19938 1064-1070.

11 Lauand F, Ruginsk SG, Rodrigues HL, Reis WL, de Castro M, Elias LL \& Antunes-Rodrigues J. Glucocorticoid modulation of atrial natriuretic peptide, oxytocin, vasopressin and Fos expression in response to osmotic, angiotensinergic and cholinergic stimulation. Neuroscience $2007 \mathbf{1 4 7} 247-257$.

12 Klussmann E, Maric K \& Rosenthal W. The mechanisms of aquaporin control in the renal collecting duct. Reviews of Physiology, Biochemistry and Pharmacology 2000141 33-95.

13 Amlal H, Chen Q, Habo K, Wang Z \& Soleimani M. Fasting downregulates renal water channel AQP2 and causes polyuria. American Journal of Physiology. Renal Physiology $20012 \mathbf{2 8 0}$ F513-F523.

14 Buemi M, Corica F, Di Pasquale G, Aloisi C, Sofi M, Casuscelli T, Floccari F, Senatore M, Corsonello A \& Frisina N. Water immersion increases urinary excretion of aquaporin-2 in healthy humans. Nephron $2000 \mathbf{8 5} 20-26$.

15 de Seigneux S, Nielsen J, Olesen ET, Dimke H, Kwon TH, Frøkiaer J \& Nielsen S. Long-term aldosterone treatment induces decreased apical but increased basolateral expression of AQP2 in CCD of rat kidney. American Journal of Physiology. Renal Physiology 2007293 F87-F99.
16 Kwon TH, Nielsen J, Knepper MA, Frokiaer J \& Nielsen S. Angiotensin II AT1 receptor blockade decreases vasopressininduced water reabsorption and AQP2 levels in NaCl-restricted rats. American Journal of Physiology. Renal Physiology $2005 \mathbf{2 8 8}$ F673-F684.

17 Lee YJ, Song IK, Jang KJ, Nielsen J, Frøkiaer J, Nielsen S \& Kwon TH. Increased AQP2 targeting in primary cultured IMCD cells in response to angiotensin II through AT1 receptor. American Journal of Physiology. Renal Physiology 2007292 F340-F350.

18 Marples D, Frokiaer J, Knepper MA \& Nielsen S. Disordered water channel expression and distribution in acquired nephrogenic diabetes insipidus. Proceedings of the Association of American Physicians 1998110 401-406.

19 Wong NL \& Tsui JK. Angiotensin II upregulates the expression of vasopressin V2 mRNA in the inner medullary collecting duct of the rat. Metabolism $2003 \mathbf{5 2} 290-295$.

20 Nishimori T, Tsujino M, Sato K, Imai T, Marumo F \& Hirata Y. Dexamethasone-induced up-regulation of adrenomedullin and atrial natriuretic peptide genes in cultured rat ventricular myocytes. Journal of Molecular and Cellular Cardiology 199729 2125-2130.

21 Fink G, Dow RC, Casley D, Johnston CI, Bennie J, Carroll S \& Dick H. Atrial natriuretic peptide is involved in the ACTH response to stress and glucocorticoid negative feedback in the rat. Journal of Endocrinology $199213537-43$.

22 Wang W, Li C, Nejsum LN, Li H, Kim SW, Kwon T-H, Jonassen TEN, Knepper MA, Thomsen K, Frokiaer J \& Nielsen S. Biphasic effects of ANP infusion in conscious, euvolumic rats: roles of AQP2 and $\mathrm{ENaC}$ trafficking. American Journal of Physiology. Renal Physiology 2006290 F530-F541.

23 Lee J, Yoo K, Kim SW, Jung KH, Ma SK, Lee YK, Kim WY, Kim J \& Choi KC. Decreased expression of aquaporin water channels in denervated rat kidney. Nephron. Physiology $2006 \mathbf{1 0 3}$ 170-178.

24 Schnizler M, Schaffert S \& Clauss W. Regulation of cAMP-sensitive colonic epithelial $\mathrm{Na}^{+}$channel in oocyte expression system. Journal of Comparative Physiology B 2001171 369-375.

25 Grossmann C, Scholz T, Rochel M, Bumke-Vogt C, Oelkers W, Pfeiffer AF, Diederich S \& Bahr V. Transactivation via the human glucocorticoid and mineralocorticoid receptor by therapeutically used steroids in CV-1 cells: a comparison of their glucocorticoid and mineralocorticoid properties. European Journal of Endocrinology $2004151397-406$.

Received 4 February 2010

Accepted 7 February 2010 